DOI: 10.35757/RPN.2012.20.01

Jerzy Holzer

\title{
UWAGI ZWIĄZANE Z PROJEKTEM „W TYGLU POKOLEŃ - ROK 1968 I JEGO WPŁYW NA STOSUNKI POLSKO-NIEMIECKIE (1968-2007)"
}

W części projektu dotyczącej wywiadów z naukowcami, publicystami i politykami przewidywano następujący zestaw pytań (z odpowiedziami w formie ustnej lub pisemnej):

(1) Czy pamięta Pan/Pani jak reagował/a na wiadomości o wydarzeniach 1968 r. w RFN?

(2) Skąd pochodziły Pana/Pani informacje o tych wydarzeniach: (a) z oficjalnych mediów PRL, (b) z zagranicznych radiostacji lub prasy (w tym RWE, BBC, Głos Ameryki), (c) z wymiany wiadomości z kolega$\mathrm{mi}$, rodzina, $(\mathrm{d}) \mathrm{z}$ innych źródeł?

(3) Czy i kiedy uzyskał/a Pan/Pani później inne ważne informacje o wydarzeniach 1968 r. w RFN?

(4) Jak Pan/Pani ocenia swą ówczesną wiedzę o tych wydarzeniach w świetle obecnej ich znajomości?

(5) Czy wydarzenia 1968 r. w RFN wpłynęły na zmianę Pana/Pani opinii na temat sytuacji w RFN oraz zagrożeń dla Polski?

(6) Czy w jakikolwiek sposób wiązał/a Pan/Pani wydarzenia $1968 \mathrm{r}$. w Polsce i w RFN?

(7) Jak reagował/a Pan/Pani osobiście na wiążącą się z polskimi (i czechosłowackimi) wydarzeniami 1968 r. propagandę antyniemiecką i jak reagowało Pana/Pani środowisko? 
(8) Czy wydarzenia 1968 r. w Polsce i w RFN wpłynęły na Pana/Pani opinię dotyczącą RFN i w ogóle Niemców jako narodu?

Lista ankietowanych zawierała 24 nazwiska. Byli to naukowcy (wśród nich najwięcej historyków i socjologów), politycy i dziennikarze, w większości czynni już w życiu publicznym w 1968 roku, rzadziej zaliczający się wówczas do generacji studenckiej. Trudno tu podawać liczbę każdej z tych trzech kategorii, bo niektórzy naukowcy parali się też, przynajmniej przejściowo, polityką.

W sumie udało się uzyskać jedynie 6 odpowiedzi, mimo przypomnień i ponagleń. Powody tego fiaska można tylko przypuszczać. Część ankietowanych to osoby bardzo zajęte, które prawdopodobnie uznały ankietę za mało ważną dla siebie lub odkładały odpowiedź i mimo przypomnień w końcu o ankiecie zapomniały. Inny powód (do jego uwzględnienia skłania też treść niektórych otrzymanych odpowiedzi) to daleko posunięty brak zainteresowania w 1968 roku badaną obecnie problematyką. Przyznanie się do tego byłoby pewnym osłabieniem własnego prestiżu. Podobnym osłabieniem prestiżu byłoby dziś przyznanie, że na wydarzenia niemieckie 1968 roku spoglądano przez pryzmat ówczesnych resentymentów. Z kolei $\mathrm{w}$ złożonych relacjach dostrzec można sporo prezentyzmu i korzystanie z nich wymagałoby daleko posuniętej krytyki źródła.

Wśród otrzymanych odpowiedzi tylko dwie, pisemna profesora Mariana Dobrosielskiego i ustna marszałka senatu Bogdana Borusewicza, były obszerne. Warto dodać, że Marian Dobrosielski czynny był wówczas w organizacji uniwersyteckiej PZPR oraz w MSZ, wkrótce został ambasadorem w Wielkiej Brytanii, a następnie wiceministrem spraw zagranicznych. Bogdan Borusewicz był uczniem szkoły średniej, aresztowany w 1968 roku, studiował po uwolnieniu w Katolickim Uniwersytecie Lubelskim.

Profesor Dobrosielski przyznaje, że „mgliście” pamięta swe reakcje na niemieckie wydarzenia 1968 roku. Relacjonuje jednak dość dokładnie, że pozytywnie przyjmował działania ruchu studenckiego i młodzieżowego, był zdziwiony negatywną reakcją lewicowych niemieckich intelektualistów (wymienia Habermasa, Adorna i Löwenthala, to raczej uproszczone pojmowanie ich postawy), natomiast późniejszą lewacką ewolucję i dzia- 
łania terrorystyczne uważał za degenerację. Dobrosielski nie dostrzega jakichkolwiek podobieństw czy relacji ruchu 1968 roku w RFN i Polsce. Uważa też, że wydarzenia 1968 roku w RFN nie wpłynęły na zmianę jego opinii na temat sytuacji w RFN oraz zagrożeń dla Polski.

Jak relacjonuje, pracując w MSZ czerpał wiedzę z czasopism zachodnich, natomiast nie miał ",ani ochoty, ani czasu” na słuchanie Wolnej Europy czy w ogóle radiostacji zagranicznych. Dobrosielski relacjonuje dalsze swe działania jako dyrektora PISM w latach siedemdziesiątych i, jak pisze, pozwoliło mu to na "głębsze poznanie" historii ruchu 1968 roku w RFN. Swą ówczesną wiedzę ocenia jednak jako „bardzo powierzchowną". Dopiero obecnie ma sprecyzowane poglądy. Za pozytywny uważa wpływ roku 1968 na pogłębienie demokracji w RFN, za negatywny radykalizację ruchu (ale też w zaskakujący sposób wiąże z 1968 rokiem stanowisko Joschki Fischera w sprawie „,agresji na Jugosławię w 1999 r.”).

Jak pisze M. Dobrosielski, propaganda antyniemiecka "polskich oficjalnych mediów była przesadna, lecz nie w pełni bezpodstawna" ze względu na odmowę uznania granicy. To zmieniła dopiero polityka koalicji SPD-FDP. Natomiast opinii o narodzie niemieckim nie zmieniał, był od zakończenia II wojny światowej „zwolennikiem porozumienia i pojednania Polski i Niemiec, Polaków i Niemców".

Marszałek Borusewicz złożył relację ustną w rozmowie z Pawłem Popielińskim. Wspomina, że „nic mnie z tymi wydarzeniami nie łączyło", „nie bardzo się tym interesowałem”, ,to był jakby margines”. W innym miejscu określa swe ówczesne stanowisko wobec wydarzeń 1968 roku w RFN jako negatywne. Wiązało się to z komunistycznym ukierunkowaniem ruchu w RFN, sprzecznym z dążeniami do demokracji. Swoją wiedzę o ruchu w RFN Borusewicz czerpał głównie z przedruków prasy zagranicznej, zamieszczanych w „Forum”.

Borusewicz mówi, że zmienił jednak pod wpływem wydarzeń w RFN w 1968 roku swą opinię na temat RFN, zrozumiał, że protestująca młodzież nie ma poglądów nacjonalistycznych i rewizjonistycznych, choć obce mu były też przejawiane przez nią tendencje komunistyczne i komunizujące. W innym miejscu Borusewicz twierdzi, że wydarzenia w Polsce w 1968 roku nie wpłynęły na jego opinię o RFN, bo była już „ugruntowaną". 
Nie wiązał w żaden sposób wydarzeń 1968 roku w RFN i w Polsce. Nadal uważa, że była to tylko koincydencja czasowa, choć w innym miejscu mówił, że była to zbieżność pokoleniowa. Negatywna ocena zmieniła się częściowo po kontaktach z ludźmi niemieckiego ruchu 1968 roku za czasów „Solidarności”. Okazali się oni „bardzo ideowymi, wartościowymi" i pod wpływem kontaktów z Polską zmienili swe poglądy. „To jest to pokolenie, które w dużej mierze teraz rządzi. Oni są dobrze nastawieni, odeszło od tego spojrzenia nacjonalistycznego".

Wedle Borusewicza propaganda antyniemiecka związana z wydarzeniami w Polsce i Czechosłowacji w 1968 roku „była tak prymitywna, że nie docierała do mego pokolenia". Wydarzenia 1968 roku, choć nieakceptowane ze względu na lewackość, ukazywały inną pluralistyczną twarz RFN.

Znacznie mniej rozwinięte były pozostałe cztery odpowiedzi. Profesor Henryk Samsonowicz uważa, że wydarzenia zagraniczne były w 1968 roku przesłonięte wydarzeniami w Polsce i interwencją w Czechosłowacji. Swą wiedzę na temat wydarzeń w RFN ocenia „bardzo nisko", choć obok informacji z oficjalnych mediów korzystał też z Głosu Ameryki oraz relacji bliskich osób, znających realia niemieckie. Ta wiedza uległa pewnemu poszerzeniu przez późniejsze kontakty z RFN. Profesor Samsonowicz pisze, że nie widział „żadnych zagrożeń dla Polski” - w domyśle ze strony RFN. Wraz ze swymi licznymi kolegami propagandę antyniemiecką traktował jako „poszukiwanie wroga”, choć koledzy z innych miast „odmiennie reagowali na «rewizjonizm niemiec$\mathrm{ki} »$, a nawet na interwencję w Czechosłowacji”.

Ponieważ byłem w tym samym warszawskim środowisku, muszę tu dodać, że opinia Henryka Samsonowicza o stosunku do propagandy antyniemieckiej, zapewne prawdziwa, wedle moich doświadczeń dość odbiega od ówczesnych poglądów wielu warszawskich historyków. Niezbyt jasna jest druga część końcowej konstatacji Samsonowicza, iż dla niego wydarzenia 1968 roku "pogłębiły niechętny stosunek do władzy w NRD, utrwaliły obawy przed rewanżyzmem w RFN". Jest to w pewnej mierze sprzeczne $z$ następnym zdaniem, że RFN „zaczęła jawić się jako «brama do wolności»". 
Profesor Włodzimierz Wesołowski swą wiedzę o wydarzeniach w RFN określa ,,jako ograniczoną", choć czerpaną nie tylko z Polskiego Radia, ale też z radiostacji zagranicznych, zwłaszcza BBC. Reagował jednak „ze smutkiem” na brutalność władz. Wesołowski nie pamięta, jak wydarzenia w RFN wpłynęły na jego opinię o RFN i zagrożenia dla Polski, nie pamięta, czy w jakikolwiek sposób wiązał wydarzenia w RFN i w Polsce, nie pamięta, czy wydarzenia te wpłynęły na jego opinie dotyczące RFN i Niemców. Jak podaje, negatywnie reagował na propagandę antyniemiecką wiążącą się z wydarzeniami 1968 roku w Polsce i Czechosłowacji.

Profesor Anna Wolff-Powęska stwierdziła, że „trudno mi wiarygodnie i uczciwie odpowiedzieć na postawione w ankiecie pytania", bo po studiach była wówczas nauczycielką szkoły podstawowej, a wydarzeniami 1968 roku się nie interesowała. Warto tu jednak dodać, że już w 1969 roku Wolff-Powęska została pracowniczką naukową Instytutu Zachodniego w Poznaniu, co świadczyłoby o ówczesnych już zainteresowaniach problematyką niemiecką.

Jedynym dziennikarzem, który odpowiedział na ankietę, był specjalista od spraw niemieckich i wieloletni korespondent polskich mediów w Niemczech Eugeniusz Guz (w 1968 roku jednak w Polsce). Odpowiedzi są krótkie. Guz pisze, że jego wiedza była „słaba, połowiczna”, czerpał ją z oficjalnych mediów oraz informacji kolegów, wydarzeń w Polsce i RFN nie wiązał ze soba, propagandę antyniemiecką on i jego środowisko przyjmowali „akceptująco”, a wydarzenia 1968 roku nie wpłynęły na jego opinie o RFN i Niemcach.

Podsumowując to, co z tych zaledwie sześciu relacji wynika:

(1) Zainteresowanie wydarzeniami w RFN i wiedza o nich były bardzo skromne.

(2) Związków między wydarzeniami w Polsce i RFN nie dostrzegano (i tak pozostało).

(3) Na propagandę antyniemiecką osoby bliżej związane z ówczesną linią partii reagowały mniej czy bardziej pozytywnie, pozostałe raczej negatywnie.

(4) Sposób formułowania odpowiedzi skłania do poglądu, że często określone są one przez obecne poglądy respondentów i wymagają daleko posuniętej ostrożności przy interpretacji. 


\section{Abstract \\ Comments on the project "In the melting pot of generations. 1968 and its impact on Polish-German relations (1968-2007)"}

The project, which consisted of contacting twenty-four people who were asked to describe, in writing or orally, their attitudes toward the events in the FRG in 1968, has produced very modest results. Only six people responded. The conclusions from their responses, in brief, are as follows:

1) the interest in, and knowledge of, the events in the RFG were very slender;

2) the events in the FRG and Poland were not perceived as being related to one another, and that is how the situation remains.

3) the people who had closer connections with the then ruling party reacted more or less positively to the anti-German propaganda, while the reaction among the others was rather more negative.

The manner in which the responses were articulated induces the view that they were frequently determined by the opinions the respondents hold today and they need thus very cautious interpretation. 